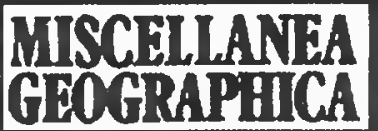

Vol. 122006 pp. 205-214

\author{
Waldemar Wilk
}

Department of Socio-Economic Geography

E-mail: wwwilk@uw.edu.pl

\title{
WESTERN EUROPEAN RETAIL CHAINS IN THE CZECH REPUBLIC, POLAND AND SLOVAKIA - SIMILARITIES AND DIFFERENCES
}

\begin{abstract}
The paper deals with an analysis the growing presence of international retail enterprises in the Central European countries of the Czech Republic, Poland and Slovakia. Results of the research show that there are differences between the Polish market and the remaining two. The differences are in the scale of investments, the investors' geographic origin, the number of stores within the network of the so called modern distribution channels (hyper-and supermarkets and discount stores). The diversity of location strategies used by Western European retail enterprises in the Central European markets is also shown, beginning with the methods of entering new markets (organic growth, acquisition of existing chains, franchising) and ending on the degree of concentration of retail stores in the largest cities of the three countries.
\end{abstract}

Key words: retail chains, Central Europe, internationalization, foreign direct investments (FDI).

\section{CONTEMPORARY CHANGES IN EUROPEAN RETAILING}

In the economic development of each region, certain characteristics and phenomena, which usually are carefully analysed, may be singled out, even ex-post. Among the most obvious phenomena in the contemporary development of retailing is the large scale growth of international enterprises initiating operations locally within a growing number of national markets. As is indicated by Wrigley [2000: 296], changes currently taking place in the organisation of retailing comprise, above all, an enormous increase of the operational scale of enterprises, especially since the second half of the nineties, in the $\mathrm{XX}^{\text {th }}$ century. This phenomenon is accompanied by an enlargement of the geographic range of operations of large enterprises, among which a peculiar elite, with particular ambitions and objectives directed at the conquest of new markets, is developing. The identified characteristics of the current changes may also be supplemented by the visible growth of significance of 
grocery retailing in the gross receipts structure of these multi-national companies.

Changes in the operational strategies of large companies are taking place, if not globally (e.g. Carrefour, Royal Ahold, Wal-Mart), then at least on the regional scale. The European market, being the home of many serious participants of the international exchange, is also an example of an ever more intense fight for new clients. Especially Western European companies, where markets may be described as mature and even as being saturated, must deal with this problem. This compels them to search for new sales markets, i.e. to thorough activeness. As it were, the natural spatial expansion territory seems to be in the markets of the Central and Eastern Europe countries, which are transforming their economies according to the principles of market economy and are attempting to integrate them with the "common market" of the European Union (EU-15). An important element of these activities is the growing liberalisation of principles of operating a business, "opening" own market as well as direct investments in production and distribution.

All this, alongside technological changes, allows us to oversee the organizational development of retailing in the network format. Actually in Poland, the Czech Republic and Slovakia majority of enterprises with a dominating position in the retail structure comes from the "old" EU countries. Their ever more frequent presence in this region is exemplified by the enlargement of store chains (from the beginning and/or as a merger/acquisition of other chains). Among examples of such integration and concentration especially visible are distribution forms based on large stores (hyper-, supermarkets, discount stores) which are the so called modern distribution channels.

In retailing, the phenomenon of concentration may occur in at least four forms. The fundamental forms are concentration of capital, organizational and technical, organizational-functional and functional-spatial [Pokorska and Maleszyk 2002:14n]. Retail chains being created reflect each of these forms of concentration. For concentration of capital, together with the creation and development of enterprises, holding companies and other forms of enterprise integration, characteristic are branch networks and diversified networks. The former have central management which is responsible for purchasing and sales management, their stores are similar in, among others, the trade offer and sales technology. In their pure form, these chains are owned by one enterprise (company). We usually deal with diversified networks when one operator groups together separate store chains, each of which offers a different combination of products and has stores of different size.

Capital concentration is accompanied by organizational and technical concentration which is characteristic of highly spacious retail chains (hyper, supermarkets, discount stores, department stores and shopping centers). According to H. Szulce [1998:61], these networks - corporate retail chains - are a specific version of branch networks (chains).

In the case of organizational-functional concentration, the so called integrated retail networks (purchasing groups, often managed by retail 
enterprises or franchising networks) are most often developed. The last retailing concentration form, (functional-spatial) expresses itself in the development of shopping centres.

We deal with each of these concentration and integration forms in the Czech Republic, Poland as well as in Slovakia. Only the scale, similarly to the number and size of the retail form networks, show regional diversification. Most often, these kinds of changes are initiated by representative offices of large Western European retail companies. At the same time, we are able to witness how several integration forms overlap, which makes difficult observing the scale and directions of these changes.

\section{FOREIGN RETAIL INVESTMENTS IN THE CENTRAL EUROPEAN COUNTRIES}

For many reasons, countries in Central Europe are the target point to which direct foreign investments are directed to an increasingly growing degree. The size and character of the market, nearness or even spatial neighbouring with the investors' home markets, joint participation in the same regional integration blocks (economic, political or military) all together result in that, during the past decade and in the past few years, capital has been flowing into the Czech Republic, Poland and Slovakia from, above all, Western European countries. Even though among various institutions there is a disparity in assessment of the scale of these investments, even according to the most conservative evaluations, up to the end of 2002, foreign direct investments (FDI) amounted here to 100 bn USD $^{1}$. Only a little less, taking into regard the market sizes, was invested in the Czech Republic (38.5 bn USD) and about 7.8 bn USD was directed into Slovakia. The scale of these investments and their impact on the economy may be better assessed comparing the amount of the invested capital to the size of the market. In this case, the Czech Republic comes out as the forerunner, where the DIZ index at the end of the year 2002 was about $55 \%$ of the annual GNP. In the case of Slovakia, this index was almost $1 / 3(32 \%)$ and in Poland, only $1 / 4$ of the GNP $(25 \%)$. Also, because of the intensity of per capita investments, the Czech economy presents itself as the best (about 3.800 USD per capita). In Poland, this index is more than thrice smaller (1.200 USD) and in Slovakia is twice smaller (1.900 USD).

There are visible differences between the examined countries in regard to investments in the retail sector. In Poland, foreign companies have only invested close to 8 bn USD. At the end of the year 2002 this totaled over $11 \%$ of all the investments. The greatest part of these investments was consumed by the construction, from the initial stage, of the branch stores

' According to UNCTAD (see: World Investment Report 2004). National sources, e.g. PAIIIZ [Polish Information and Foreign Investment Agency] gives an amount exceeding 64.5 billion USD for the middle of 2003 
network or the take over of existing retail networks. In Slovakia, up to 2001, this amounted to $11.3 \%$. Also in the Czech Republic, where investments in the manufacturing sector decisively predominate. The share of retail in FDI was close to the level of the neighboring countries and in 2002 amounted to about 11.9\% [Agentura pro podporu... 2004].

The development of these networks by foreign investors takes place in accordance with one of several strategies. As is shown by Domański [2001:88-89], it may be the strategy of direct investments which entails the purchasing of a foreign commercial company or some sort of a global strategy in which an investor reconstructs, in a foreign market, a sales formula developed earlier in the home market or in other markets. Examples of such investments may also be found in Poland, the Czech Republic and Slovakia with a similar assortment of policies, store design and décor, principles of location selection. Of assistance in explaining the methods of entrance of investors into Eastern European markets is probably the application of one of the alternate ideas [Horovitz and Kumar, after: Domański, 2001:93n], when the target market is assessed from the perspective of entry barriers and cultural distance to the home market. In our opinion, this allows to explain, at least partially, why investors from Germany, Austria or France (more rarely from United Kingdom or Norway) undertake to build from the start (organic development) retail networks in the examined countries. They do not have to set up joint-venture companies. Only in order to more quickly obtain a share of the market the two remaining forms of accessing the market may be chosen (franchising or purchase of a network, if such was developed earlier).

Further to the origin of companies investing the three countries, there are only small differences, especially between the Polish and Czech and Slovakian markets. In Poland, a much greater engagement in the construction of commercial networks is demonstrated by the French capital (Carrefour, Casino, Leclerc, ITM), whereas in the Czech Republic and Slovakia German enterprises (Rewe, Tengelmann), Austrian (Julius Meinl) and Belgian (Delhaize Le Lion) are much more engaged. Currently, Dutch (Royal Ahold) and German (Schwarz Group) enterprises seem to be the most active players on all the three markets. Activity of companies such as Royal Ahold dates back to the beginning of the nineties in the $\mathrm{XX}^{\text {th }}$ century [Szczyrba 2000:18]. The engagement of British and Dutch investors seems to be shared by all the three countries (the Tesco and Royal Ahold network).

Regardless of the market, in each of the three countries, the presence of foreign investors in retailing begins with the construction of a large-scale retail store chain, mainly hypermarkets and supermarkets. Development of discount store networks was initiated in the second half of the last decade. Subsequent similarities in investing strategies may be observed in the process of moving new investments from the largest cities (mainly capitals) to centers located lower on the hierarchy level of the settlement system. 


\section{REGIONAL DIFFERENCES IN RETAIL NETWORK DEVELOPMENT}

One may look from two perspectives at the problem of diversification of the commercial network development in the examined countries. First of all, as a difference between these countries stemming from the company presence (as partially shown above), their network size and the number of retail stores. Secondly, as a difference in the presence of foreign companies in towns (centers) of different size, including the capital cities.

Primary differences in the size of retail networks, with a division into three main categories, i.e. modern distribution channels, are shown in tables 1-3. They contain information on the level of development of the hypermarket, supermarket and discount store networks in the Czech Republic, Poland and Slovakia.

Table 1.

The largest foreign retail networks in the Czech Republic in 2003

\begin{tabular}{|l|c|c|c|c|c|}
\hline $\begin{array}{c}\text { Network } \\
\text { (Enterprise) }\end{array}$ & $\begin{array}{c}\text { Number of } \\
\text { retail stores }\end{array}$ & $\begin{array}{c}\text { Network } \\
\text { (Enterprise) }\end{array}$ & $\begin{array}{c}\text { Number of } \\
\text { retail stores }\end{array}$ & \multicolumn{1}{|c|}{$\begin{array}{c}\text { Network } \\
\text { (Enterprise) }\end{array}$} & $\begin{array}{c}\text { Number of } \\
\text { retail stores }\end{array}$ \\
\hline \multicolumn{2}{|c|}{ Hypermarkets } & \multicolumn{2}{c|}{ Supermarkets } & \multicolumn{2}{c|}{ Discount Stores } \\
\hline $\begin{array}{l}\text { Kaufland } \\
\text { (Schwarz) }\end{array}$ & 53 & $\begin{array}{l}\text { Albert } \\
\text { (Royal Ahold) }\end{array}$ & 177 & $\begin{array}{l}\text { Penny Market } \\
\text { (Rewe) }\end{array}$ & 142 \\
\hline $\begin{array}{l}\text { Hypernova } \\
\text { (Royal Ahold) }\end{array}$ & 43 & Delvita & 94 & $\begin{array}{l}\text { Plus Discount } \\
\text { (Tengelmann) }\end{array}$ & 107 \\
\hline Tesco & 16 & Julius Meinl & 94 & $\begin{array}{l}\text { Lidl } \\
\text { (Schwarz) }\end{array}$ & 51 \\
\hline Interspar (SPAR) & 14 & Billa (Rewe) & 73 & Norma & 29 \\
\hline Globus & 10 & Edeka & 39 & & \\
\hline Carrefour & 9 & & & & \\
\hline
\end{tabular}

Source: Ročenka Českeho a Slovenskeho obchodu 2004 (2004), p.12.

Table 2.

The largest foreign retail networks in Poland in mid 2004

\begin{tabular}{|c|c|c|c|c|c|}
\hline $\begin{array}{c}\text { Network } \\
\text { (Enterprise) }\end{array}$ & $\begin{array}{l}\text { Number of } \\
\text { retail stores }\end{array}$ & $\begin{array}{c}\text { Network } \\
\text { (Enterprise) }\end{array}$ & $\begin{array}{l}\text { Number of } \\
\text { retail stores }\end{array}$ & $\begin{array}{c}\text { Network } \\
\text { (Enterprise) }\end{array}$ & $\begin{array}{l}\text { Number of } \\
\text { retail stores }\end{array}$ \\
\hline \multicolumn{2}{|c|}{ Hypermarkets } & \multicolumn{2}{|c|}{ Supermarkets } & \multicolumn{2}{|c|}{ Discount Stores } \\
\hline Tesco & 38 & $\begin{array}{l}\text { Albert } \\
\text { (Royal Ahold) }\end{array}$ & 164 & $\begin{array}{l}\text { Biedronka } \\
(\mathrm{JMD})\end{array}$ & 670 \\
\hline $\begin{array}{l}\text { Kaufland } \\
\text { (Schwarz) }\end{array}$ & 36 & $\begin{array}{l}\text { Intermarche } \\
\text { (ITM) }\end{array}$ & 93 & $\begin{array}{l}\text { Plus Discount } \\
\text { (Tengelmann) }\end{array}$ & 154 \\
\hline Real (Metro) & 27 & $\begin{array}{l}\text { Champion } \\
\text { (Carrefour) }\end{array}$ & 68 & $\begin{array}{l}\text { Leader Price } \\
\text { (Casino) }\end{array}$ & 138 \\
\hline $\begin{array}{l}\text { Hypernova } \\
\text { (Royal Ahold) }\end{array}$ & 25 & $\begin{array}{l}\text { MiniMAL } \\
\text { (Rewe) }\end{array}$ & 27 & Lidl (Schwarz) & 86 \\
\hline Auchan & 18 & Elea & 13 & $\begin{array}{l}\text { Netto (Dansk } \\
\text { Supermarked) }\end{array}$ & 77 \\
\hline Geant & 17 & Julius Meinl & 9 & SPAR & 26 \\
\hline Carrefour & 15 & & & & \\
\hline
\end{tabular}

Source: own elaboration on the basis of company information (network operators). 
Table 3.

The largest foreign retail networks in Slovakia in 2003

\begin{tabular}{|l|c|c|c|c|c|}
\hline $\begin{array}{c}\text { Network } \\
\text { (Enterprise) }\end{array}$ & $\begin{array}{c}\text { Number } \\
\text { retail stores }\end{array}$ & $\begin{array}{c}\text { Network } \\
\text { (Enterprise) }\end{array}$ & $\begin{array}{c}\text { Number } \\
\text { retail stores }\end{array}$ & $\begin{array}{c}\text { Network } \\
\text { (Enterprise) }\end{array}$ & $\begin{array}{c}\text { Number of } \\
\text { retail stores }\end{array}$ \\
\hline \multicolumn{2}{|c|}{ Hipermarkets } & \multicolumn{2}{|c|}{ Supermarkets } & \multicolumn{2}{|c|}{ Discount stores } \\
\hline $\begin{array}{l}\text { Kaufland } \\
\text { (Schwarz) }\end{array}$ & 16 & Billa (Rewe) & 55 & $\begin{array}{l}\text { Lidl } \\
\text { (Schwarz) }\end{array}$ & 12 \\
\hline $\begin{array}{l}\text { Hypernova } \\
\text { (Royal Ahold) }\end{array}$ & 15 & Delvita & 15 & & \\
\hline Tesco & 15 & & & & \\
\hline Carrefour & 4 & & & & \\
\hline
\end{tabular}

Source: own elaboration on the basis of Ročenka Českeho a Slovenskeho obchodu 2004 (2004) and company information.

A comparison of the content of tables 1-3 indicates a large similarity between Western European companies active on the local market. The Czech market seems to have a relatively well developed hypermarket network. The number of retail stores in some networks is comparable with or even greater than on the Polish market, e.g. Kaufland or Hypernova. By the end of 2003, there were about 160 hypermarkets in the Czech Republic. On the other hand, in Poland the presence of French operators is noticeable, even though their networks do not have the largest number of retail stores.

As far as the number of supermarkets in all the examined countries, there undoubtedly is one leader with an outstanding number of retail stores. In the Czech Republic and in Poland, it is the Albert (Royal Ahold) network and in Slovakia, the Billa network (Rewe). Further down the line are networks specific to the given market, i.e. Delvita and Julius Meinl in the Czech Republic and Intermarché and Champion in Poland. Furthermore, attention is focused on the slower development of supermarket networks in Slovakia.

The largest discount store network have been developed in each of the countries by somewhat different groups of investors. In Poland, the most numerous is the Jeronimo Martins Dystrybucja network with almost 700 retail stores. It is owned by Jeronimo Martins from Portugal (the Biedronka network), in the Czech Republic it is the German Rewe group (the Penny Market network) and in Slovakia, the Schwarz German group (the Lidl network, currently in the initial stage of development) (see fig. 2).

In each of the examined countries there is an individual settlement network pattern. At the same time, there is a different scale of domination (advantage) of the capital city. Prague is inhabited by over $11.4 \%$ of all inhabitants of the Czech Republic, Bratislava is home to about $8 \%$ of the inhabitants of Slovakia and $4.4 \%$ of the overall population inhabits Warsaw. Besides the number of inhabitants (households), important from the point of view of operators of retail networks, these cities attract investors because of their capital city functions and nearness to information sources. 


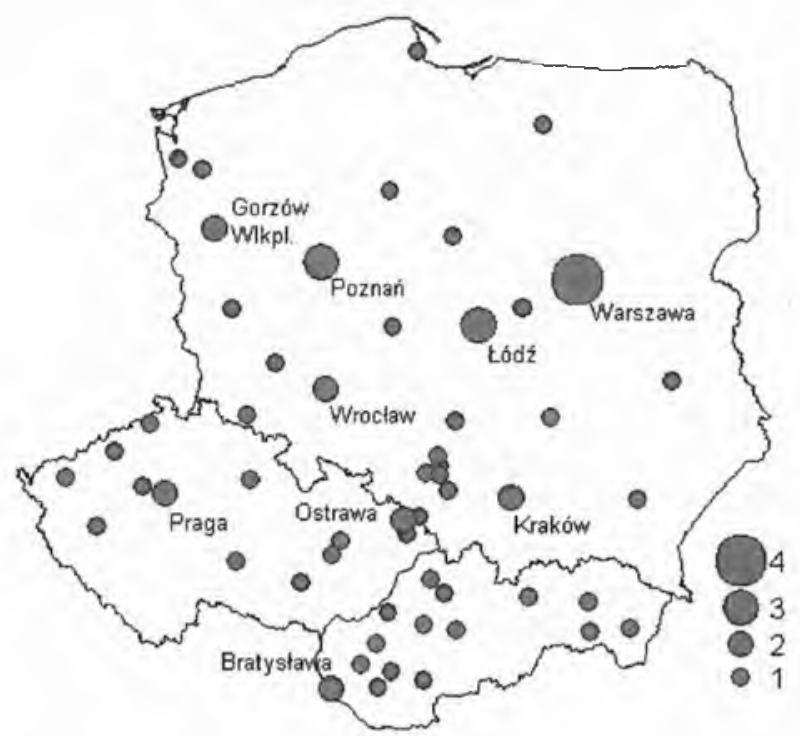

Fig. 1. Distribution of Tesco hypermarkets in 2003

Source: own elaboration on the basis of company information

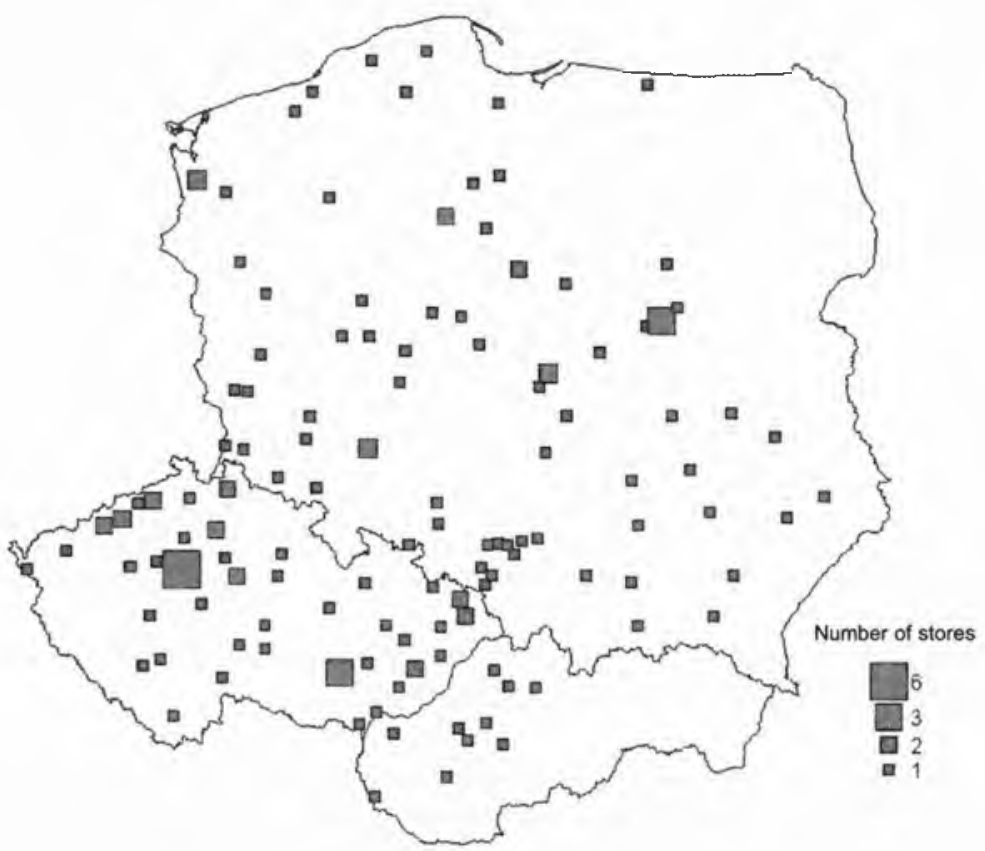

Fig. 2. Distribution of the Lidl discount store chain (Schwarz Group) in 2004

Source: own elaboration on the basis of company information (chain operators) 
Construction of numerous networks began in the capital cities and only in time, following partial saturation of the market, as in the case of hypermarkets, investments were transferred to smaller towns. The exception is Billa in the Czech Republic (first retail store was in Brno) and in Slovakia (first store in Trnava) or the Globus hypermarkets in the Czech Republic (Brno). However, large cities continue to be the locations of the greatest number of large scale retail stores (see fig. 1). It is difficult to find this regularity when analysing the directions and development pace of discount store networks which direct their offer to the less affluent population segment. The distribution of the number of supermarkets is similar even though regional differences are visible (tab. 4). In the case of Poland, in moving on to smaller towns, a relatively greater share in the total number of supermarkets may be expected. This regularity does not only regard the smallest town (population $<20 \mathrm{~K}$ ). It is different in the Czech Republic, where supermarkets in the Albert network are to be found relatively more often in towns with a population of over 100 thousand inhabitants (tab. 4).

Table 4.

Town size structure according to the population number (2003)

\begin{tabular}{|c|c|c|c|c|c|c|}
\hline \multirow{3}{*}{$\begin{array}{c}\text { Town size } \\
\text { (as of population } \\
\text { number) }\end{array}$} & \multicolumn{2}{|c|}{ Czech Republic } & \multicolumn{2}{|c|}{ Poland } & \multicolumn{2}{|c|}{ Slovakia } \\
\hline & \multicolumn{2}{|c|}{ Share of town group in: } & \multicolumn{2}{|c|}{ Share of town group in: } & \multicolumn{2}{|c|}{ Share of town group in } \\
\hline & $\begin{array}{c}\text { Urban } \\
\text { population }\end{array}$ & $\begin{array}{l}\text { Number } \\
\text { of outlets }\end{array}$ & $\begin{array}{c}\text { Urban } \\
\text { population }\end{array}$ & $\begin{array}{l}\text { Number } \\
\text { of outlets }\end{array}$ & $\begin{array}{c}\text { Urban } \\
\text { population }\end{array}$ & $\begin{array}{l}\text { Number } \\
\text { of outlets }\end{array}$ \\
\hline$<20 \mathrm{~K}$ & $40,0(595)^{*}$ & $\begin{array}{c}\text { A - } \\
\text { B } 27,0\end{array}$ & $20,8(663)^{*}$ & $\begin{array}{c}\text { A - } \\
\text { B } 12,2\end{array}$ & $29,4(99)^{*}$ & A - \\
\hline $20-50 \mathrm{~K}$ & $16,0(41)$ & $\begin{array}{l}\text { A } 7,1 \\
\text { B } 21,3\end{array}$ & $17,4(132)$ & $\begin{array}{l}\text { A } 5,6 \\
\text { B } 28,7\end{array}$ & $27,4(28)$ & A 26,7 \\
\hline $50-100 \mathrm{~K}$ & $16,2(17)$ & $\begin{array}{l}\text { A } 50,0 \\
\text { B } 15,7\end{array}$ & $14,1(49)$ & $\begin{array}{l}\text { A } 11,1 \\
\text { B } 17,1\end{array}$ & $21,4(9)$ & A 53,3 \\
\hline $100-200 \mathrm{~K}$ & $3,5(2)$ & $\begin{array}{l}\text { A } 7,1 \\
\text { B } 3,9 \\
\end{array}$ & $12,7(22)$ & $\begin{array}{l}\text { A } 25,0 \\
\text { B } 18,3 \\
\end{array}$ & - & A - \\
\hline $200-500 \mathrm{~K}$ & $9,1(2)$ & $\begin{array}{l}\text { A } 21,4 \\
\text { B } 15,7\end{array}$ & $16,1(13)$ & $\begin{array}{l}\text { A } 22,2 \\
\text { B } 10,4\end{array}$ & $21,8(2)$ & A 20,0 \\
\hline$>500 \mathrm{~K}$ & $15,2(1)$ & $\begin{array}{l}\text { A } 14,3 \\
\text { B } 16,3 \\
\end{array}$ & $18,9(5)$ & $\begin{array}{l}\text { A } 36,1 \\
\text { B } 13,4 \\
\end{array}$ & - & $A-$ \\
\hline Total & $100,0(658)$ & $\mathrm{X}$ & $100,0(884)$ & $\mathrm{x}$ & $100,0(138)$ & $\mathrm{x}$ \\
\hline
\end{tabular}

A -Tesco hypermarkets; B - Albert supermarkets; $\left({ }^{\star}\right)$ - in parenthesis is the number of towns in group

Source: own elaboration on the basis of http://www.world-gazetteer.com and www. stat.gov.pl [11.10.2004] and company information

The results of comparisons between the number of the existing hypermarkets and the size of a given town are not surprising. The greatest number of retail stores may be found in the largest towns, which is exemplified by the Tesco network in Poland. In the Czech Republic and in Slovakia, however, a somewhat different picture may be observed because most often their 
stores are located in towns with a population of 50-100 thousand. Separate research on the role of towns as retail network nodes [Wilk, 2004] indicates that in capital cities, for example in Warsaw, not only the greatest number of hypermarkets is located but also there are retail stores belonging the greatest number of chains (operators).

On the other hand, smaller town preference is characteristic to the discount store distribution. A proof of this is the distribution pattern of the largest networks in each of the analyzed countries in the middle of 2004. In the Czech Republic it is the Penny Market (Rewe, 148 stores), in Poland, the Biedronka network (JMD, 676 stores) and in Slovakia, Lidl (Schwarz, 12 stores). In towns with a population of up to 50 thousand there are $79 \%$ Penny Market stores (the Czech Republic), 52\% Biedronka stores (Poland) and $58 \%$ stores of the Lidl network (Slovakia). Additionally, regional differences in the distribution of the Lidl retail store network may be indicated, which occur in every examined country. Their location is similar in the Czech Republic and Slovakia (58-60\% in towns with population of less than 50 thousand) whereas in Poland, the share of this group does not exceed $35 \%$.

Such a spatial distribution pattern of large-scale retail stores was determined by numerous factors, including those which are not analysed in this paper. Among the most important, without any doubt, are shopping preferences of inhabitants of each of the discussed countries. The influence of legal regulations and different scope and intensity of protests organized by local communities (mainly, small-scale independent traders) against locating new large-scale retail stores may not be overlooked.

\section{CONCLUSIONS}

Even though each retail network was established according to an internal development strategy and the specific character of the local market, their present development in Central European countries shows several common characteristics. Western European investors, in the beginning of their operations in a new market, usually selected, besides a few exceptions, the largest cities, i.e. country capitals. Further growth of foreign networks in the Czech Republic, Poland and Slovakia may continue to take place according to the present approach. In a short time, this will lead to market saturation and problems with finding locations for new stores. Already many network operators in Poland or the Czech Republic, after exhausting possibilities of building new hypermarkets, have begun investing in somewhat smaller facilities (catchment area), locating them in small towns.

One of the analysis [AT Kearney, 2003], even shows a relative saturation of retail market in Poland and the Czech Republic because of the presence of international network stores and shopping space, especially in shopping centres. For this reason, the report recommends avoidance of subsequent investments in these markets. This only concerns the Polish and Czech markets. 
As far as organization, in the near future, one may expect an intensification of the integration phenomenon in retailing. Already now, some enterprises have joint regional boards of management for their operations in the Czech Republic, Poland and Slovakia, e.g. Royal Ahold. In the future this may also include the unification of the supply chain system and logistics.

It seems justifiable to monitor these changes even because of the scale of interrelations between operators of the largest retail facilities and their suppliers. Under numerous circumstances, this regards a relatively large group of entities because the largest retail enterprises sometimes cooperate with several thousand producers, majority of them coming from the local market. Each retail company must also react to the consumers' changing behaviour and needs, the operations of competition and the ever more numerous networks being build with national capital.

\section{REFERENCES}

Agentura pro podporu podnikani a investic, 2004, [www.czechinvest.org, 12.10.2004].

AT Ke arn ey, 2003, Global Retail Development Index. Emerging Markets: Priorities for Food Retailers. [www.atkearney.com, 10.10.2004].

D o m a ń s ki T., 2001, Strategie marketingowe dużych sieci handlowych [Marketing strategies in large retail networks; in Polish], Warszawa-Łódź: Wydawnictwo Naukowe PWN.

Pok orska B., Maleszyk E., 2002, Koncentracja $i$ integracja $w$ handlu wewnętrznym [Concentration and integration in internal trade; in Polish], Warszawa: PWE.

Ročenka Českeho a Slovenskeho obchodu 2004 (2004) Praha: Česke a slovenske odborné nakladatelstvi.

Szczyrba Z., 2000, Uzemni rozvoj maloobchodni sité, Urbanismus a Uzemni Rozuoj, 3(1), pp.18-24.

Szulce H., 1998, Struktury $i$ strategie $w$ handlu /Structures and strategies in retailing; in Polish/, Warszawa: Polskie Wydawnictwo Ekonomiczne.

World Investment Report 2004: The Shift Towards Services (2004) New York and Geneva: UNCTAD.

W il k W., 2004, Miasta jako węzły sieci handlowych [Cities as retail network nodes, in Polish], Prace $i$ Studia Geograficzne, Warszawa: Uniwersytet Warszawski, Wydzial Geografii i Studiów Regionalnych (in press).

Wrigley N., 2000, The Globalization of Retail Capital: Themes for Economic Geography, [in:] Clark G.L et al.. (eds.) The Oxford Handbook of Economic Geography, Oxford: Oxford University Press, pp. 292-313.

English translation: Małgorzata Miłaszewska 